\title{
Nationalism, Self-Determination, and Empire
}

\author{
Brian S. Mueller
}

Daniel Immerwahr, How to Hide an Empire: A History of the Greater United States (New York: Farrar, Straus and Giroux, 2019). 516 pp. Hardcover \$30.00 USD.

Adom Getachew, Worldmaking After Empire: The Rise and Fall of Self-Determination (Princeton: Princeton University Press, 2019). 288 pp. Hardcover \$35.00 USD.

Natasha Zaretsky, Radiation Nation: Three Mile Island and the Political Transformation of the 1970s (New York: Columbia University Press, 2018). 312 pp. Paperback $\$ 35.00$ USD.

Look at a map and what you see is a world divided into nation-states. Yet these lines do not always tell the whole story. In fact, hidden beneath the arbitrary masses of land on maps is a history of imperialism and resistance. Whether the colonizer or colonized, nationalism is a fundamental part of this story. Each of the books under review highlight how various actors on the world stage understood and reconfigured nationalism to achieve their particular goals at home and abroad.

Daniel Immerwahr joins the longstanding debate among historians over whether the United States deserves the appellation of imperialist. Yet, Immerwahr's entrance into the feud is refreshing due to his ability to employ old evidence in new ways. To defend his argument that the United States is and always has been an empire, Immerwahr, in his fantastic How to Hide an Empire: A History of the Greater United States, targets what he calls the "logo map," a term he borrowed from Benedict Anderson, which is the accepted image of the United States that appears on maps. Immerwahr takes issue with the "logo map" because it distorts US history. The most visible distortion is the inconspicuous absence of Alaska and Hawaii. Also missing is Puerto Rico, Guam, American Samoa, and the countless other smaller islands. As an alternative, Immerwahr proposes a map more representative of what he calls the "Greater United States." To ignore the parts that make up the Greater United States is to downplay the reality of US empire. By the 1940s, these additional lands included a population of nearly 19 million people. In terms of land, almost a fifth of the Greater United States existed outside of the contiguous United States. Though nowhere near the geographic scope of the British Empire, Immer- 
wahr points out that "the United States' empire was nonetheless sizable. ${ }^{1}$

Immerwahr tells his story in "three acts," beginning with white settlers taking the lands occupied by North American Indians, followed by the annexation of overseas territory, and concluding his story with a series of seeming reversals that involved the United States relinquishing its territories in the aftermath of World War II. While not downplaying US westward expansion, Immerwahr's story picks up steam in the second act with a captivating account of how a desire for bat guano spurred US imperialism. With the Guano Islands Act of 1856, nearly one hundred islands came under the control of the United States. The legislation allowed US citizens to search for islands in the Pacific and Caribbean with ample bat droppings and declare them part of the United States. After some initial reluctance to pass the measure in Congress, proponents of the bill convinced the skeptics that since the islands would not support habitation, the law did not give official support to colonialism. Yet, these arguments proved premature, as the Supreme Court heard a case centred on workers' action against the Navassa Phosphate Company. Though no government existed on these islands, the Supreme Court ruled that US laws extended to these isolated dots of land in the middle of the ocean. President Benjamin Harrison seemed to back the Supreme Court decision when he sent the USS Kearsage to check conditions on the island and later proclaimed during his annual message to Congress that corporations operating on these lands were under the jurisdiction of the US government and laws. In essence, the legislation, the Supreme Court decision, and Harrison's unequivocal defense of the ruling meant that America's borders now extended beyond the North American continent. Such logic would eventually lead to the building of airfields on tiny islands across the Pacific.

At the same time, the invisibility of US empire on the "logo map" conformed with the growing hesitancy to extend US laws to its territorial possessions. When the United States won the Spanish-American war, Immerwahr suggests the newly acquired lands posed a "trilemma." He writes, "republicanism, white supremacy, and overseas expansion - the country could have at most two." 2 The problem stemmed from the fact that these new lands, unlike previous territory, had a large non-white population. Given the difficulties involved with restraining expansion, either republicanism or white supremacy had to go. The former would mean denying the peoples of these lands the same rights as Americans, while the latter involved granting Puerto Rico, the Philippines, and other territories statehood down the road. In the Insular Cases of the early twentieth century, the Supreme Court distinguished between territories, which existed as part of the union and therefore came under the protection of the Constitution, and the "unincorporated" lands outside of the United States, such as the Philippines and Puerto Rico, which did not have the same protections. In fact, the "logo map" became popular within a decade of the end of the Spanish-American war. By 1910, the imperial maneuvers of the United States, once celebrated, became viewed by some Americans as, in the words of Immerwahr, "a regrettable drunken binge."” As the likelihood of US in- 
volvement in World War I increased, so too did nationalism, but US citizens reconstrued the nation as being only those 48 states in North America, not as earlier maps of the "Greater United States" had, with insets of the United States' various territorial possessions.

Events following World War II seemed to portend an end to American empire, but Immerwahr urges caution in seeing this era as a break from earlier epochs and notes the increasingly prominent structure of informal imperialism. The United States finally allowed the Philippines its independence and bestowed "commonwealth" status upon Puerto Rico. Meanwhile, Alaska and Hawaii achieved statehood. Anti-imperialism and anti-colonialism likely played a part, but so too did technology. To begin with, many products no longer required the resources found in foreign lands. Nor did the United States have to annex new lands when advances in transportation, communication, and other areas allowed the same benefits. Moreover, standardization of everything from language to signage to hardware, notably screws, made physical control of these lands unnecessary. Globalization of this sort did not occur on its own, but rather through the purposeful actions of the US military, with the intent of creating a less controversial alternative to colonialism. A "mastery of logistics," Immerwahr argues, allowed the United States to avoid having to claim physical possession of colonies, at least in their entirety. ${ }^{4}$ Instead, the United States would use its capabilities in building infrastructure to create new ports, airstrips, storage depots, and other structures marking a US presence. According to Immerwahr, synthetics "remade geopolitics." 5 No longer did the United States have to worry about access to resources, which in the past had led to control over foreign lands and conflict. Even oil shortages never reached the level that would lead to a possible invasion by the United States of the Middle East. The bases that remained after World War II accounted for a total area less than the state of Connecticut. And while the Greater United States had a population in which 51 percent, due largely to postwar US occupations of Japan and elsewhere, lived outside of the continental United States, that number declined substantially, reaching only two percent in 1960 .

Combined with the logistical advances that allowed the United States to reach virtually any locale on the globe through air travel, territory lost its luster. Joseph Stalin learned this lesson in 1948 when he prevented US access to Berlin. In response, the US military initiated the successful airlift. As the "arsenal of democracy" during World War II, the United States could also demand that standardization of everything from aircraft parts to screws conform to US specifications. The creation of NATO expanded US dominance into peacetime as US allies agreed to change their guns and aircraft to match those preferred by the United States. While large swaths of land no longer mattered, the United States came to rely more heavily on its earliest possessions, tiny islands. Already in the 1930s, under the direction of Ernest Gruening, the United States attempted to reclaim control over these territories, which "acquired special importance in the twilight of formal empire." These 
pieces of land proved far easier to control in the post-World War II moment when decolonization pressures made maintaining an empire difficult. Even in the Philippines, which had gained independence in 1946, the United States demanded military bases. A similar process occurred across US possessions. Immerwahr has called this system of worldwide bases "Baselandia." US bases brought with them many benefits, nearly all of them financial, but it also created tension, as exemplified by the protests carried out by the bases' neighbours in Japan. Moreover, the United States unwittingly helped grow Japan's economy, which would have important ramifications for US industry in future decades. Immerwahr describes this as America's "pointillist empire" because US territories represented nothing more than a point on the map. Though small, these bases caused much anger, which usually led to protests, but other times much worse. After all, Immerwahr reminds us that "September 11 was, in large part, retaliation against the United States for its empire of bases." $^{\text {"7 }}$

Besides helping to shed light on America's hidden empire, Immerwahr's book also illustrates the precarious nature of decolonization and territorial independence. Despite the successful anti-colonial movement waged by Third World nations across the globe in the aftermath of World War II, independence remained elusive. As Adom Getachew shows in her excellent study, Worldmaking After Empire: The Rise and Fall of Self-Determination, true self-determination hinged on the transformation of the entire global order. Getachew details how, for many Third World leaders involved in the decolonization movement, their interests extended beyond the nation-state. Getachew rejects the notion that nationalism was "parochial and anti-universal." 8 People like Michael Manley of Jamaica and Julius Nyerere of Tanzania realized that self-determination required more than breaking free from the shackles of colonialism. True independence would come only with the "reordering" of the global order in the legal, political, and economic realms. Thus, these individuals went far beyond rebuilding their own societies to "worldmaking." As another leader in the anti-colonial movement, Kwame Nkrumah of Ghana, understood, becoming a nation-state and becoming a part of the international community of nations represented only the first step in true independence since dependency inevitably followed in the footsteps of decolonization. Thus "unequal integration," as Getachew calls it, ensured that recently decolonized nations would remain in an inferior position as they had to meet all the "obligations" of membership in the international society, but received only some of the "rights" given to other European countries. ${ }^{10}$ Together, Immerwahr's and Getachew's books do a tremendous job of illustrating how empires remained in spite of the efforts of the decolonization movement.

The inequality among states decried by Nkrumah had roots in earlier efforts to rid the world of empire. The "racialized international hierarchy" discussed by Getachew appeared in the League of Nations, as evidenced by the experiences of league members Ethiopia and Liberia. ${ }^{11}$ These nations, along with self-governing 
British dominions like India and smaller states in Eastern Europe, had to exist in a sort of purgatory, neither a colony, but not yet a state with all the privileges accorded to such entities. In the case of Ethiopia, the league used inclusion in the international body to gain authority to solve Ethiopia's slave labour problem and thus act as a benevolent overseer directing the begotten nation in the proper direction toward civilization. Consequently, Ethiopia was a mandate of the league in all but name. Liberia faced a similar existence in the league. While investigating the use of slave labour in Ethiopia and Liberia, the league looked at the countries in isolation, ignoring how a regional economic system enmeshed in colonialism created these conditions. Rather than looking externally, the league focused on internal problems, mainly leadership by blacks. As such, Ethiopia and Liberia had to go above and beyond what was expected of other league members to stay within the organization. For Ethiopia, its existence on the fringe of the league had significant ramifications. Italy, which would invade Ethiopia in 1935, defended its actions by pointing to the nation's purported inability to govern itself and its lack of success towards becoming civilized, the same arguments previously employed by the league. Moreover, Italy construed its invasion as being no different from earlier league attempts to transform Ethiopia.

Adoption in 1960 of United Nations General Assembly Resolution 1514, known as Declaration on the Granting of Independence to Colonial Countries and Peoples, was a major victory for the decolonization movement. At the same time, it also represented a retrenchment in the sense that by couching self-determination in terms of human rights, which proved most amenable to other members of the General Assembly, the resolution had to discard its economic demands, particularly relating to sovereign control over natural resources. Yet, from the perspective of the anti-colonial nationalists, the collective right of self-determination, which would free nations from imperial control, made possible the protection of individual human rights. In other words, with democratic self-government now a reality following the passage of resolution 1514, protection of individual human rights would follow naturally.

In reality, however, the link between human rights and self-determination posed a threat to post-colonial independence. The ethnic conflict that ravaged Nigeria between 1967 and 1970 led to growing doubts about self-determination. During this time, the Igbo people sought to secede from Nigeria and form their own state, Biafra. In response, the Organization of African Unity (OAU) offered assistance, but only to mediate between the two sides. The OAU did not consider the Igbo's pleas for self-determination as valid. The leader of Tanzania, Julius Nyerere, disagreed with the OAU's approach. He not only argued that the Biafrans deserved their own separate nation due to Nigeria's borders being based on old colonial designs, but he also linked the abuses against the Igbo to human rights violations. Unlike Nyerere, who continued to speak in the language of self-determination, international human rights organizations, notably Doctors Without Borders, focused 
on the individuals harmed by the post-colonial governments, which fed into the growing chorus of voices linking the rise of self-determination to greater levels of human rights abuses. Such thinking would lead to increasing numbers of humanitarian interventions in the Third World.

As anti-colonial leaders faced a series of hurdles in their quest for national independence and self-determination, various Third World voices put forth blueprints for a new world order. In fact, one of the most significant contributions of Getachew's study is an analysis of these various plans. To show the strain of thinking present in the Third World that placed national independence in a place of secondary importance, Getachew looks at Ghana’s leader, Kwame Nkrumah, who popularized the notion of neocolonialism. Nkrumah, borrowing from Lenin's idea of neocolonialism, understood the limits placed on national sovereignty by the continued economic domination of former colonies by imperial powers. Thus, Nkrumah included in Ghana's constitution a clause that would allow the nation to give up some of its sovereign rights to join a Union of African States. From his perspective, federation would allow the young nations to become more economically self-reliant through involvement in a regional economy separate from both the United States and the European Economic Community. Though regional in focus, federation would have important ramifications for the position of post-colonial nations in the international realm as well. After recognizing the economic benefits of federation, participating nations would look for ways to use their newfound strength to thwart foreign political and military interference in their internal affairs and gain more power in international bodies like the UN.

For inspiration Nkrumah, along with Eric Williams, a professor at Howard University in the United States involved with the West Indian Federation, looked to America in 1776. Yet, rather than celebrate America's independence, Nkrumah and Williams pointed to the nation's continued economic dependence on imperial Britain, which retained a hold on America until the thirteen states federated in 1787. Nkrumah and Williams also found favour with federalism because it allowed for a strong centralized government. While critics worried that such a structure would transpose hierarchy to the regional level, Nkrumah and Williams claimed that avoiding foreign domination required centralization. Not surprisingly, not all Third World leaders supported federalism. Michael Manley of Jamaica stood as a staunch critic of a strong federal state as proposed for the West Indian Federation. Manly wanted to limit the central government's authority to diplomatic and defense issues and leave economic matters to individual countries.

The internationalism of the anti-colonial nationalists was most evident in the construction and promotion of a New International Economic Order (NIEO) by the Global South. The consequences of colonialism extended into the post-colonial world, which meant that overcoming unequal economic development required a new global economic system. Though much has been written about the NIEO, Getachew sheds new light on the topic by showing how, through their promotion 
of self-reliance, Manley and Nyerere had more in mind with the NIEO than simply strengthening national sovereignty. Thus, "overcoming dependence was to be realized domestically through socialist policies and internationally in the New International Economic Order," Getachew writes. ${ }^{12}$ In other words, Nyerere and Manley hoped to decolonize both the internal economies of Third World nations and the global economy. Moreover, Getachew looks beyond the NIEO's demand for a massive redistribution of wealth from North to South and illustrates how postcolonial leaders sought to place the global economy under the control of a truly representative international body like the United Nations General Assembly.

For various reasons, the United States retained its empire in spite of the efforts of critics like Nkrumah and Manley. Economics surely played a role in this, but so too did America's massive nuclear arsenal, which allowed the United States to maintain its hegemony over the capitalist world. Yet, during the post-Vietnam War era, all things nuclear came under fire from an unlikely constituency within the United States: white, working-class conservatives. This story is told in Natasha Zaretsky's Radiation Nation: Three Mile Island and the Political Transformation of the 1970s. Zaretsky calls for a greater recognition of the growth of "biotic nationalism" in the 1970s. Especially pronounced among conservatives, these aggrieved citizens borrowed from dissidents of the 1960s as they felt like the government sacrificed their bodies in pursuit of global supremacy during the Cold War. ${ }^{13}$ Thus, the antiwar, ecological, civil rights, and women's movements of the 1960s inspired the "patriotic Americans" response to the Three Mile Island disaster that helped transform conservatism. Following the disaster, conservative residents of the Susquehanna River Valley exhibited "a new post-Vietnam interrogation of authority" and became awakened to the ecological threat to their bodies. Combined, these concerns led to what Zaretsky has called "a post-Vietnam patriotic body politics" among these conservatives. $^{14}$

The focus on body politics placed women at the centre of the story. Whereas in the past male soldiers returned home from battle and castigated the government for its failure to care for wounded veterans, the Three Mile Island fiasco transferred "patriotic body politics" to women, "from the martial arena to the familial one," in the words of Zaretsky. ${ }^{15}$ A similar transference occurred in the realm of psychology. Residents of central Pennsylvania began to compare their psychological distress as a form of post-traumatic stress disorder (PTSD), which up until that point had usually inflicted soldiers returning from Vietnam. Others also referred to themselves as POWs unable to escape radiation. In the minds of these conservatives, the government failed to protect its own citizens from its nuclear power. A "culture of dissociation," in which weapons of mass destruction, nuclear and otherwise, protected US citizens from foreign enemies but also threatened their own existence, allowed the United States to amass a massive defensive posture. ${ }^{16}$ The accident at Three Mile Island, even more than 1950s and 1960s protests against the testing of atomic weapons, helped deconstruct the "culture of dissociation" created 
by the US government.

Yet, rather than use their newfound cynicism of the US government to criticize US foreign policy more generally, these activists remained avowed nationalists, evincing no concern for the world beyond the United States. Unlike the antiwar protestors, "radiation activists," as Zaretsky has called those Americans seeking redress for being exposed to nuclear fallout, voiced concern over their own "victimization," which they compared to the decline of the nation as a whole. Thus, they sought, in the words of Zaretsky, "the restoration of a lost patriotism and the reconstitution of national power." These "reluctant activists," moreover, claimed that unlike leftists protesting the US empire or promoting Earth Day out of a supposed moral duty, they did so out of concern for their own survival. ${ }^{17}$

This tendency also found expression in the burgeoning anti-nuclear movement of the late 1970s and 1980s. Despite the opposition to nuclear war by freeze activists, the movement remained committed to "a biotic, body-centered nationalism" imbued with a patriotism concerned only with the survival of America and its people. Zaretsky has pointed to a "temporal emphasis on futurity" predominant among freeze supporters that led to them focusing almost entirely on a future outbreak of nuclear war while ignoring how conventional weapons used in present conflicts caused much death and destruction. ${ }^{18}$ This outlook also tended to prioritize the likely American lives lost during a nuclear exchange over those persons killed in faraway lands. Such a strategy, however, allowed the freeze activists to avoid any linkage to more radical opponents of US foreign policy that sought to criticize US imperialism. By actively instructing its members to avoid any mention of Vietnam, freeze leaders "deployed a conscious strategy of depolarization," according to Zaretsky. ${ }^{19}$ Consequently, in the midst of this massive campaign to stop the nuclear arms race in its track, the United States continued to intervene in lands near and far in pursuit of global supremacy.

Taken together, these books shed light on the prevalence and power of empire and illustrate why, even in the aftermath of the US failure in Vietnam, Americans refused to change course in terms of foreign policy. In showing how much territory the United States physically controlled in the past, and present for that matter, Immerwahr lays bare for all to see the empire created by the United States. At the same time, by transitioning the lens to the Third World, Getachew illustrates how other forms of control, both economic and political, thwarted efforts for selfdetermination and ensured the continuation of empire. In short, these two books prove that empires applied their power in direct and indirect ways to maintain a hierarchy of nation-states. The post-Vietnam era offered perhaps the best opportunity for the United States to dismantle its empire, both physical and otherwise, but other concerns proved more pressing for Americans. Like radiation, US empire is not always visible, but in the 1970s and 1980s, that did not stop Americans from targeting the former while ignoring the latter. Zaretsky's success in linking the protests at Three Mile Island to the transformation of nationalism does much to further our 
understanding of why the United States did not change course in the global arena following the Vietnam War.

Maps produced today look far different from those of even just twentyfive or thirty years ago. Yet, despite these changes to the world's nations and borders, much remains the same. The United States is still the dominant player in the political and economic realm. Though radical ideas radiated outward from the antiwar, civil rights, feminist, and ecological movements of the 1960s to the conservative residents of the Susquehanna River Valley following the Three Mile Island accident in the 1970s, this critical gaze did not extend to US activities abroad. Meanwhile, the post-colonial vision offered by the Third World could not withstand the onslaught of neoliberalism. As a result, the Global South continues to struggle to get out from under the weight of an unequal global capitalist system. And while the inclusion of ecological concerns into the nationalism of the Three Mile Island victims helped distinguish it from earlier forms of nationalism, such a worldview is ill-suited in the contemporary era. After all, the current ecological threat, climate change, ignores territorial boundaries, meaning that a different, more internationalist approach is necessary. 


\section{NOTES}

${ }^{1}$ Daniel Immerwahr, How to Hide an Empire: A History of the Greater United States (New York: Farrar, Straus and Giroux, 2019), 11.

${ }^{2}$ Immerwahr, 80.

${ }^{3}$ Immerwahr, 110.

${ }^{4}$ Immerwahr, 216.

${ }^{5}$ Immerwahr, 274.

${ }^{6}$ Immerwahr, 343.

${ }^{7}$ Immerwahr, 382.

${ }^{8}$ Adom Getachew, Worldmaking After Empire: The Rise and Fall of Self-Determination (Princeton: Princeton University Press, 2019), 3.

${ }^{9}$ Getachew, 2.

${ }^{10}$ Getachew, 17-18.

${ }^{11}$ Getachew, 40.

12 Getachew, 154.

${ }^{13}$ Natasha Zaretsky, Radiation Nation: Three Mile Island and the Political Transformation of the 1970s (New York: Columbia University Press, 2018), xvi.

14 Zaretsky, 9.

15 Zaretsky, 95.

16 Zaretsky, 15.

17 Zaretsky, 55-56.

18 Zaretsky, 171.

19 Zaretsky, 173. 